\title{
In situ gross growth rates of Emiliania huxleyi in enclosures with different phosphate loadings revealed by diel changes in DNA content
}

\author{
J. D. L. van Bleijswijk, M. J. W. Veldhuis \\ Netherlands Institute for Sea Research, PO Box 59, 1790 AB Den Burg (Texel), The Netherlands
}

\begin{abstract}
The in situ specific growth rate of the nanoplankton species Emiliania huxleyi can be successfully derived from analysis of die] DNA synthesis patterns. Calculated growth rates $\left(\mu_{\mathrm{DNA}}\right)$ were in close agreement with growth rates determined from cell counts in laboratory cultures of $E$. huxleyi. For E. huxleyi populations in large outdoor enclosures (temp. $=7.9$ to $10.2^{\circ} \mathrm{C}$ ), $\mu_{\mathrm{DNA}}$ ranged from 0.36 to $0.76 \mathrm{~d}^{-1}$. Combining data on (net) changes in cell number of the enclosed populations with the calculated $\mu_{\mathrm{DNA}}$ values provided information on the total specific loss rates of $E$. huxleyi (caused by grazing, viral infections and autolysis). The initial and mid-exponential phases of $E$. huxleyi blooming were characterized by relatively high $\mu_{\mathrm{DNA}}$ values. At a later stage, following the depletion of nutrients in the water, $\mu_{\mathrm{D} w \mathrm{~N}}$ decreased. Specific loss rates ranged from 0.07 to $0.63 \mathrm{~d}^{-1}$ and no particular trend in time was noticeable. E. huxleyi populations in enclosures with different phosphate loadings did not show significant differences in $\mu_{\mathrm{DNA}}$ in contrast, differences in loss rates were indisputable. Loss rates were low $\left(0.07\right.$ to $\left.0.35 \mathrm{~d}^{-1}\right)$ in fertilized enclosures with low and intermediate phosphate concentrations, allowing extensive E. huxleyi blooming. In the fertilized enclosure with high phosphate loadings $\left(\mathrm{PO}_{4}\right.$ $\left.>2.6 \mathrm{mmol} \mathrm{m} \mathrm{m}^{-3}\right)$ and in the unfertilized oligotrophic enclosure losses were high $\left(0.33\right.$ to $\left.0.63 \mathrm{~d}^{-1}\right)$ preventing blooming of E. huxleyi. We concluded that nutrients were not limiting gross $E$. huxleyi growth but that they affected E. huxleyi losses by changing the phytoplankton composition and biomass
\end{abstract}

KEY WORDS: Cell division - Diel cycle - DNA - Emiliania huxleyi Flow cytometry - Growth rate . Loss rate Phosphate Phytoplankton-Prymnesiophyceae

\section{INTRODUCTION}

Emiliania huxleyi (Lohmann) Hay \& Mohler is a coccolithophorid in the nanoplankton size class which occurs world-wide. Surface blooms of this characteristic species cover, on average, an area of $1.4 \times 10^{6} \mathrm{~km}^{2}$ each year, of which $71 \%$ is located in the subpolar latitudes (Brown \& Yoder 1994). Because E. huxleyi is a major pelagic producer of calcium carbonate and an important contributor to dimethyl sulphide emissions in the atmosphere, an understanding of $E$. huxleyi blooming contributes to the understanding of our global climate (Charlson et al. 1987, Holligan 1992, Malin et al. 1992, Westbroek et al. 1993).

During May 1992, we participated in a field study which had the aim of assessing the effects of nutrients (particularly phosphate) on Emiliania huxleyi bloom- ing. Experiments were performed in large outdoor enclosures which varied in their nutrient loadings Time series of phytoplankton abundance, biomass and production were described (Egge \& Heimdal 1994، Van Bleijswijk et al. 1994a, Van der Wal et al. 1994). Abundance is a net parameter, affected by growth and loss processes. To understand the effects of nutrients on the abundance of E. huxleyi we needed to know the intrinsic growth rate of this specific species, independent of grazing, lysis and sedimentation. Our strategy was to determine the gross growth rate based on analysis of the E. huxleyi cell cycle.

Essentially, the rate at which cells in a (partially) phased population proceed through the 3 phases of the division cycle $\left(G_{1}, S\right.$ and $G_{2} M$ phase, defined by Howard \& Pelc 1953) was determined using DNA staining techniques and flow cytometry. The growth 
rate was then calculated according to the mitotic index method of McDuff \& Chisholm (1982) as improved by Carpenter \& Chang (1988). This method has been tested with computer simulations (Carpenter \& Chang 1988) and laboratory cultures of the dinoflagellate Heterocapsa triquetra (Chang \& Carpenter 1988) and has already been applied in the field (Chang \& Carpenter 1991, 1994, Vaulot et al. pers. comm.). It was shown that grazing does not affect the accuracy of the method (Chang \& Dam 1993).

We describe here the first results of calculations of in situ specific growth rate for the coccolithophorid Emiliania huxleyi during 3 phases of bloom development: the onset of blooming, the exponential increase and the bloom peak. Special attention is given to the effect of nutrients (phosphate in particular) on gross $E$. huxleyi growth. Additionally, we present total E. huxleyi specific loss rates, which were determined by comparing gross and net growth rates.

\section{MATERIALS AND METHODS}

In order to test whether analysis of diel changes in DNA content would provide reliable estimates of the gross growth rate of Emiliania huxleyi populations, we first applied the method to laboratory cultures of this species. Three strains were involved: Ch24-90 (calcified type $A_{1}$ isolated in 1990 from the northern North Sea), Ch25-90 (calcified type B, isolated in 1990 from the northern North Sea) and LN (naked type A, clone of strain $L$ which was isolated from the Oslo fjord in 1968 by Prof. Dr E. Paasche). Type A and B cells differ in their morphology and the immunological properties of their coccolith polysaccharide (Van Bleijswijk et al. 1991, Young \& Westbroek 1991). Ch24-90 and Ch2590 were grown at 15 and $10^{\circ} \mathrm{C}$, respectively, in dilution cultures under various photon flux densities (ranging from 5.9 to $155.0 \mu \mathrm{mol}$ photons $\mathrm{m}^{-2} \mathrm{~s}^{-1}$ ) which were supplied in an artificial 16:8 h L:D cycle (Van Bleijswijk et al. 1994b). Of these cultures, 8 were light limited and 2 were phosphate limited. In addition, Ch24-90 and LN were sampled from batch cultures during temperature-limited growth $\left(14^{\circ} \mathrm{C}\right)$.

Natural Emiliania huxleyi populations were sampled in 1992 from large seawater enclosures (volume $11 \mathrm{~m}^{3}$ ) located in a fjord, $20 \mathrm{~km}$ south of the Norwegian city of Bergen (Egge \& Heimdal 1994). The enclosures (and their duplicates), numbered 3,4,5 and 6, differed in their initial nutrient content. Enclosure 4 remained unfertilized and initially contained field concentrations of $5.0 \mathrm{mmol} \mathrm{m}^{-3}$ nitrate and $0.3 \mathrm{mmol} \mathrm{m} \mathrm{m}^{-3}$ phosphate. In Enclosures 3, 5 and 6, the initial concentration of nitrate was set at $18 \mathrm{mmol} \mathrm{m} \mathrm{m}^{-3}$ and of phosphate at $0.4,4.5$ and $1.0 \mathrm{mmol} \mathrm{m}^{-3}$, respectively (low, high and intermediate phosphate loading). Duplicate enclosures showed a very similar development in their phytoplankton contents (Egge \& Heimdal 1994). Moreover, the unfertilized enclosures and the surrounding fjord water behaved very similarly. It was concluded that the enclosure system itself had negligible effects on phytoplankton development and that the differences between enclosures largely resulted from the different nutrient regimes (see also Egge 1993).

In enclosures with low and intermediate phosphate loadings, intense blooms of Emiliania huxleyi developed, as determined from cell counts and measurements of the particulate inorganic carbon standing stock (Egge \& Heimdal 1994, Van Bleijswijk et al. 1994a). High phosphate loadings favoured other phytoplankton species and had negative effects on the absolute abundance of E. huxleyi. E. huxleyi numbers also remained low in the unfertilized enclosures.

We took samples on 2-3 May, 11-12 May and 18-19 May (Enclosures 3 and 6 only). These dates corresponded with the initial phase, the mid-exponential growth phase and the peak of the Emiliania huxleyi bloom, respectively (Fig. 1). The natural L:D cycle was approximately 16:8 h. For further details on the 1992 enclosure experiments see Sarsia special volume 79 (1994).

For analysis of diel patterns in cellular DNA content, populations were sampled every second hour over a period of at least $24 \mathrm{~h}$. Samples taken from the enclosures were first prefiltered over a $10 \mu \mathrm{m}$ sieve to remove large organisms, aggregates and fecal pellets. Then, the $<10 \mu \mathrm{m}$ plankton fraction (which includes Emiliania huxleyi) was concentrated by filtering 1 to 31 of the prefiltered subsamples under low pressure on polycarbonate filters $(0.8 \mu \mathrm{m}$ pore diameter, Isopore). Cells were washed off these filters by shaking the

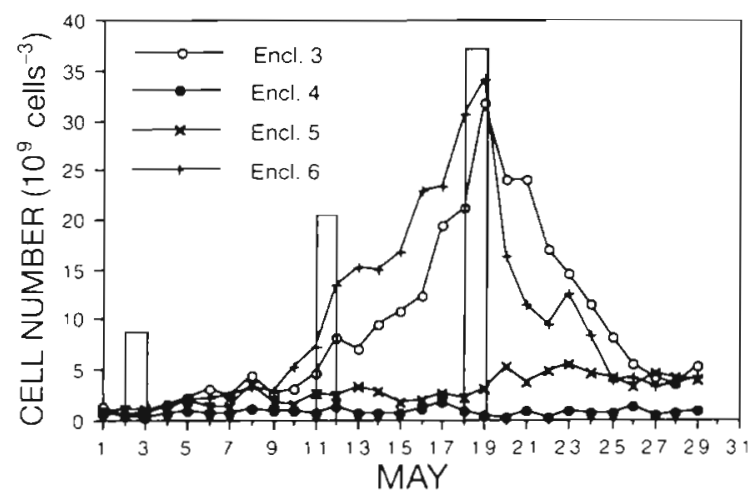

Fig. 1. Emiliania huxleyi. Time series of cell numbers in 4 natural seawater enclosures (data from J. K. Egge). Enclosures 3. 5 and 6 were fertilized with nitrate, and with phosphate in low, high and intermediate concentrations, respectively (see Table 1). Enclosure 4 was not fertilized. Bars indicate periods when gross growth rates were determined 
filters in $5 \mathrm{ml}$ of the corresponding prefiltered subsamples. The concentrated enclosure samples were then treated similarly to the laboratory culture samples. Cells were harvested in Eppendorf vessels by centrifugation ( $8 \mathrm{~min}$ at $450 \times \mathrm{g}$ ), fixed in ice-cold methanol and stored at $-50^{\circ} \mathrm{C}$. Prior to analysis they were washed 2 times in a cold solution of phosphatebuffered saline $\left(0.15 \mathrm{~mol} \mathrm{l}^{-1} \mathrm{PBS}, \mathrm{pH} 7.9\right)$, and incubated in the same solution with RNAse (final concentrations: $40 \mathrm{mg} \mathrm{l}^{-1}$ RNAse A, Sigma R-4875) for $1 \mathrm{~h}$ at $10^{\circ} \mathrm{C}$. Cellular DNA was stained with propidium iodide (PI) (final concentration: $5 \mathrm{mg} \mathrm{l}^{-1}$ ) and analysed with a flow cytometer (EPICS CS, excitation wavelength 488 $\mathrm{nm}$ ). Emission fluorescence of PI-stained nuclei was measured above $610 \mathrm{~nm}$.

The stained preparations of the enclosure samples contained many plankton species from various trophic levels. Nevertheless, we were able to select Emiliania huxleyi populations in the flow cytometer histograms by presuming that their forward light scatter (angle: 0.5 to $19^{\circ}$ ) and side scatter (angle: 19 to $117^{\circ}$ ) characteristics were in close agreement with the corresponding signals of the unialgal laboratory cultures. Microscopical observations confirmed our interpretation of the flow cytometer histograms.

At least 15000 Emiliania huxleyi cells were analysed per sample to obtain reliable DNA histograms. The $G_{1}$ and $G_{2} M$ peaks were fitted by normal curves, the $S$ phase by a polynomial curve using non-linear Marquardt algorithms ('Multicycle' software package, Phoenix Flow Systems). The fractions of cells in the different phases $\left(f_{\mathrm{G}_{1}}, f_{\mathrm{S}}\right.$ and $\left.f_{\mathrm{G}_{2} \mathrm{M}}\right)$ were then obtained from the area of the corresponding fitted curves.

In situ gross growth rates $\left(\mu_{\mathrm{DNA},} \mathrm{d}^{-1}\right)$ were calculated according to the formula of Carpenter \& Chang (1988) with minor revisions of Vaulot (1992) and given the restriction that $\mu_{\mathrm{DNA}}<\mu_{\max }$ :

$\mu_{\mathrm{DNA}}=\frac{24}{\left(t_{\mathrm{s}}\right)_{\Sigma} \cdot 2\left(t_{2}-t_{1}+k \cdot t_{\mathrm{p}}\right)} \sum_{i=1}^{D}\left(t_{\mathrm{s}}\right)_{i} \ln \left[1+f_{\mathrm{S}}\left(t_{3}\right)+f_{\mathrm{C}_{2} \mathrm{M}}\left(t_{1}\right)\right]$

where $\mu_{\max }=$ maximum possible growth rate (for Emiliania huxleyi: $\mu_{\max }=1.85 \mathrm{~d}^{-1}$; Brand 1982); $\left(t_{\mathrm{s}}\right)_{\Sigma}=$ total sample interval $(\mathrm{h}) ; t_{2}=$ time $(\mathrm{h})$ where $\mathrm{d} f_{\mathrm{G}_{2} \mathrm{M}} / \mathrm{d} t=0 ; t_{1}=$ time (h) where $\mathrm{d} f_{\mathrm{S}} / \mathrm{d} t=0 ; k=0,1,2,3, \ldots ; t_{\mathrm{p}}=$ entraining period ( $24 \mathrm{~h}$ for our samples); $\left(t_{s}\right)_{i}=$ sampling interval (h) of sample $i_{i} t_{1}=$ time (h) of obtaining the ith sample; $f_{\mathrm{S}}$ and $f_{\mathrm{G}_{2} \mathrm{M}}=$ fraction of population in $\mathrm{S}$ and $\mathrm{G}_{2} \mathrm{M}$ phase respectively. $t_{2}$ and $t_{1}$ were determined after fitting 4 th degree polynomial functions through the data points of, respectively, $f_{\mathrm{G}_{2} \mathrm{M}}$ and $f_{\mathrm{S}}$ against time.

Cell numbers were determined in fresh samples with a Fuchs-Rosenthal haemocytometer and after drying on cellulose acetate filters as described in Van Bleijswijk et al. (1994a). The net specific growth rate ( $\mu_{\text {cell }}$, $\mathrm{d}^{-1}$ ) was averaged over 5 consecutive days and calculated as:

$$
\mu_{\text {cell }}=\frac{\ln \left(N_{d}\right)_{i+1}-\ln \left(N_{d}\right)_{i}}{d_{i+1}-d_{i}}
$$

where $\left(N_{d}\right)_{t+1}$ and $\left(N_{d}\right)_{4}$ are, respectively, the cell numbers at Day $i+1$ and Day $i$.

\section{RESULTS AND DISCUSSION}

During all diel sampling series, the DNA histograms clearly changed with time. This shows that phased cell division not only occurred in laboratory cultures, but also in the fertilized Enclosures 3,5 and 6 as well as in the unmanipulated Enclosure 4. As an example, the results for Enclosure 3 on 18-19 May are presented in Fig. 2. At 12 and 14 h, 1 major peak is observed in the DNA histograms. This peak represents $G_{1}$ cells (gap 1 cells), which contain 1 DNA equivalent. At $17 \mathrm{~h}$, the peak is broadened towards the right side because a part of the population (S cells) has started to synthesise extra DNA. Subsequently (20 to $26 \mathrm{~h}$ ), the cluster of $S$ cells gradually shifts to the right, as the mean cellular DNA content of the cluster increases due to the synthesis of DNA. It is noteworthy that the $G_{1}$ and $S$ peaks move apart between 22 and $28 \mathrm{~h}$. Apparently, no (or few) cells transgress the boundary between the $G_{1}$ and the $\mathrm{S}$ phase during this dark period. At $26 \mathrm{~h}$ a substantial fraction of the population contains 2 DNA equivalents $\left(G_{2} M\right.$ cells $=$ gap 2 and mitosis cells $)$. After $26 \mathrm{~h}$ the number of $G_{2} M$ cells decreases whereas the number of $G_{1}$ cells increases due to mitosis which continues until $34 \mathrm{~h}$ ( $=10 \mathrm{~h}$ in the preceding cycle).

The peaks in the DNA histograms showed a good fit by normal curves. The standard variabilities (CVs) of the fitted $G_{1}$ and $G_{2} M$ peaks ranged from 6 to $15 \%$. The ratio between the mean DNA contents of $\mathrm{G}_{2} M / \mathrm{G}_{1}$ cells ranged from 1.93 to 2.21 .

\section{Gross growth rates}

In the laboratory cultures, $\mu_{\text {cell }}$ ranged from 0.20 to $1.24 \mathrm{~d}^{-1}$. Over this entire range of growth rates $\mu_{\text {cell }}$ and $\mu_{\text {DNA }}$ were in close agreement (Fig. 3 ). The deviation of the regression line from the $1: 1$ relationship falls within the relative error of the method (18 to $22 \%$ ) as calculated by Chang \& Carpenter (1990) and Chang \& Dam (1993). The result clearly shows that analysis of diel changes in cellular DNA content of Emiliania huxleyi provides reliable estimates of the gross growth rate. It is noteworthy that the success of the method does not depend on the growth limiting factor. This is because the length of the terminal phase $\left(\mathrm{S}+\mathrm{G}_{2}+\mathrm{M}\right)$ is determined for every population (Carpenter \& Chang 1988). 


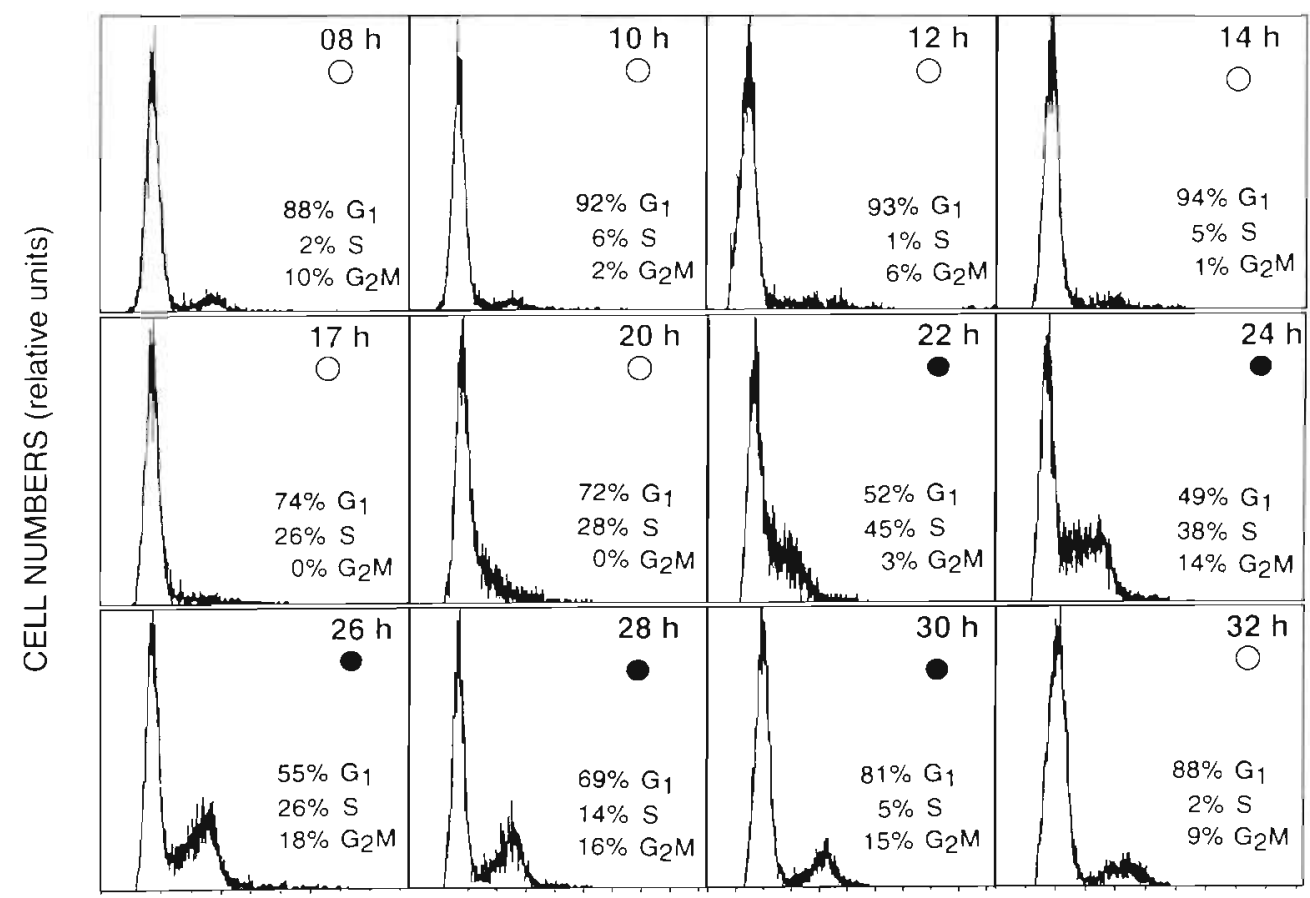

DNA CONTENT (relative units)
Fig. 2. Emiliania huxleyi. Diel changes in DNA content of the population in Enclosure 3 sampled on 18-19 May 1992. (O) Light period (06 to $22 \mathrm{~h}$ ): () dark period (22 to $30 \mathrm{~h})$. Percentages of the population in the $G_{1}$, $\mathrm{S}$ and $\mathrm{G}_{2} \mathrm{M}$ phases are indicated in each panel

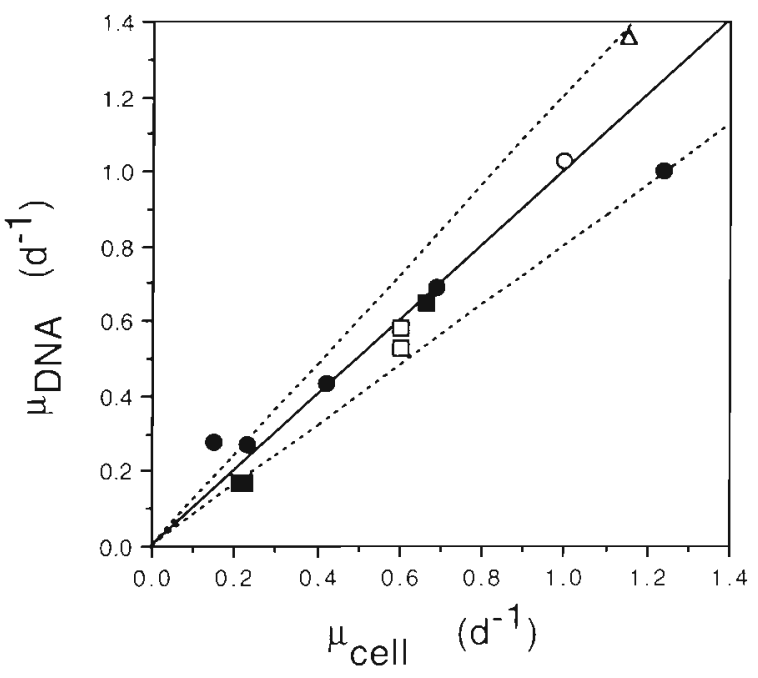

Fig. 3. Emiliania huxleyi. Calculated specific gross growth rate $\left(\mu_{D N_{A}}, d^{-1}\right)$ versus the measured specific growth rate ( $\mu_{\text {cell. }}$ $\mathrm{d}^{-1}$ ) of laboratory cultures. $\mu_{\mathrm{DNA}}$ was calculated on the basis of diel changes in cellular DNA content (Carpenter \& Chang $1988)_{i} \mu_{\text {cell }}$ was determined from changes in cell number. Continuous line $=1: 1$ relationship between $\mu_{\mathrm{DNA}}$ and $\mu_{\text {cell }}$. Dotted lines indicate interval in which datapoints do not significantly deviate from this $1: 1$ relationship assuming a relative error of $20 \%$ in $\mu_{\text {DNA. }}$. Strain Ch24-90, light limited (O) strain Ch24-90, temperature limited: $(\Delta)$ strain LN, temperature limited; (ם) strain Ch25-90, light limited $(\square)$ strain Ch25-90, phosphate limited
For the enclosure populations, calculated gross growth rates ranged from 0.36 to $0.76 \mathrm{~d}^{-1}$ (Table 1). At water temperatures of 7.9 to $8.2^{\circ} \mathrm{C}$, growth rates of 0.63 to $0.76 \mathrm{~d}^{-1}$ are probably the maximum possible values. In well-adapted laboratory cultures of Emiliania huxleyi, grown at $10^{\circ} \mathrm{C}$ and under optimal light and nutrient conditions, growth rates of $0.81 \mathrm{~d}^{-1}$ have been measured (Van Bleijswijk et al. 1994b).

Gross growth rates ( $\left.\mu_{\mathrm{DNA}}\right)$ were comparable on $2-3$ May, during the initial phase of blooming, and on 11-12 May, during the mid-exponential growth phase, for all enclosures (Table 1). On 18-19 May, growth continued at the same rate $\left(0.42 \mathrm{~d}^{-1}\right)$ in Enclosure 3 whereas in Enclosure $6, \mu_{\text {DNA }}$ was reduced by $43 \%$ (to $\left.0.36 \mathrm{~d}^{-1}\right)$. The reduction in $\mu_{\mathrm{DNA}}$ in Enclosure 6 was preceded by a depletion of nutrients $(N$ and $P$ $<0.1 \mathrm{mmol} \mathrm{m} \mathrm{m}^{-3}$ on 14,15 and $\left.16 \mathrm{May}\right)$. After 17 May nutrient concentrations slightly increased, probably due to lysis and remineralization of phytoplankton. cells.

Comparing Emiliania huxleyi populations in enclosures with different nutrient loadings, no significant differences were found in $\mu_{\mathrm{DNA}}$ when relative errors of $20 \%$ were assumed. This indicates that the nutrient conditions did not limit gross E. huxleyi growth. Indirectly, this corroborates our hypothesis that E. huxleyi was growing at its maximum rate under the given temperature conditions. 
Table 1 Emiliania huxleyi. Calculated gross specific growth rates $\left(\mu_{D N A}, d^{-1}\right)$ and measured net specific growth rates $\left(\mu_{c e l l}, d^{-1}\right)$ of semi-natural populations. Samples were taken from 4 outdoor enclosures with different nutrient conditions. $\mu_{D N A}$ was calculated on the basis of diel changes in cellular DNA content using the formula in the 'Materials and methods' with $k=0 ; \mu_{c e l l}$ was determined from changes in E. huxleyi cell numbers on 5 consecutive days; $E$. huxleyi specific loss rate (d $\left.{ }^{-1}\right)$ was calculated as loss $=\mu_{\text {DNA }}-\mu_{c \text { ell }}$. PAR: photosynthetically available radiation $(400$ to $700 \mathrm{~nm})$ at $2 \mathrm{~m}$ depth in the enclosures

\begin{tabular}{|c|c|c|c|c|c|c|c|c|c|}
\hline Enclosure & $\begin{array}{c}\text { Date } \\
(1992)\end{array}$ & $\begin{array}{l}\mu_{\mathrm{DNA}} \\
\left(\mathrm{d}^{-1}\right)\end{array}$ & $\begin{array}{c}\mu_{\mathrm{ce} \|} \\
\left(\mathrm{d}^{-1}\right)\end{array}$ & $\begin{array}{l}\text { Loss } \\
\left(d^{-1}\right)\end{array}$ & $\begin{array}{l}\text { Cell no. } \\
\left(10^{9} \mathrm{~m}^{-3}\right)\end{array}$ & $\begin{array}{l}\text { Temp. } \\
\left({ }^{\circ} \mathrm{C}\right)\end{array}$ & $\begin{array}{c}\text { PAR } \\
\left(\mathrm{mol} \mathrm{m}^{-2} \mathrm{~d}^{-1}\right)\end{array}$ & $\begin{aligned} & \mathrm{NH}_{4}{ }^{+}+\mathrm{NO}_{x} \\
&\left(\mathrm{mmol} \mathrm{m}^{-3}\right)\end{aligned}$ & $\begin{array}{c}\mathrm{PO}_{4}{ }^{3-} \\
\left(\mathrm{mmol} \mathrm{m}^{-3}\right)\end{array}$ \\
\hline 3 & 2 May & 0.51 & 0.44 & 0.07 & 0.52 & 7.9 & 10.1 & 14.34 & 0.25 \\
\hline 4 & 2 May & 0.64 & 0.13 & $0.51^{\circ}$ & 0.45 & 7.9 & 10.1 & 0.72 & 0.08 \\
\hline 5 & 2 May & 0.49 & 0.16 & $0.33^{\circ}$ & 1.00 & 7.9 & 12.0 & 13.95 & 4.69 \\
\hline 6 & 2 May & 0.59 & 0.39 & $0.20^{\circ}$ & 0.45 & 7.9 & 10.6 & 13.40 & 1.04 \\
\hline 3 & $11 \mathrm{May}$ & 0.43 & 0.26 & $0.17^{\circ}$ & 4.58 & 8.2 & 8.6 & 10.84 & 0.08 \\
\hline 4 & $11 \mathrm{May}$ & 0.63 & 0.00 & $0.63^{\circ}$ & 0.75 & 8.2 & 11.7 & 0.38 & 0.02 \\
\hline 5 & $11 \mathrm{May}$ & 0.76 & 0.17 & $0.59^{\circ}$ & 2.70 & 8.2 & 6.5 & 2.73 & 2.66 \\
\hline 6 & 11 May & 0.63 & 0.28 & $0.35^{\circ}$ & 7.35 & 8.2 & 6.5 & 3.73 & 0.20 \\
\hline 3 & 18 May & 0.42 & 0.25 & $0.17^{\circ}$ & 21.20 & 10.2 & 8.9 & 5.94 & 0.26 \\
\hline 6 & 18 May & 0.36 & 0.11 & $0.25^{\circ}$ & 30.50 & 10.2 & 5.6 & 1.30 & 0.45 \\
\hline
\end{tabular}

\section{Loss rates}

We obtained estimates of the total Emiliania huxleyi specific loss rate $\left(\mathrm{d}^{-1}\right)$ in the enclosures by comparing the calculated gross growth rates with the averaged net growth rates determined from cell counts on 5 consecutive days. Loss rates ranged from 0.07 to $0.63 \mathrm{~d}^{-1}$ (Table 1) and no significant trend in time was noticeable. We do not know which factors are responsible for the calculated losses but it is clear that they determined the ultimate success of bloom formation. In general, our estimates of the total specific loss rates are higher than the grazing rates measured by several colleagues in Enclosures 3 and 6: combined data of Gonzales \& Van der Wal (pers. comm.) and Nejstgaard et al. (1994) suggest a constant grazing on E. huxleyi by mesozooplankton throughout the experiment of 0.05 to $0.10 \mathrm{~d}^{-1}$ in Enclosures 3 and 6 . In the same enclosures microzooplankton did not graze significantly on $E$. huxleyi (Nejstgaard et al. 1994). Viral-induced mortality could not be measured before 19 May (due to the methodology) but was very high afterwards in Enclosures 3 and 6 ( $1.3 d^{-1}$ in Enclosure 3 on 19-22 May and $2.0 \mathrm{~d}^{-1}$ in Enclosure 6 on 19-24 May; Egge \& Heimdal 1994). General lysis was not quantified in any of the enclosures. The sedimentation rate was assumed to be low throughout the experiment due to the presence of an air lift.

Loss rates clearly differed in enclosures with different nutrient loadings (Table 1). Losses were 0.07 to $0.17 \mathrm{~d}^{-1}$ in Enclosure 3, 0.20 to $0.35 \mathrm{~d}^{-1}$ in Enclosure 6 , 0.33 to $0.59 \mathrm{~d}^{-1}$ in Enclosure 5 and 0.51 to $0.63 \mathrm{~d}^{-1}$ in Enclosure 4. We had already observed that the relative contribution of Emiliania huxleyi to the total phyto- plankton biomass decreased with increasing phosphate loading in the fertilized enclosures (Van Bleijswijk et al. 1994a). The present results show that at the same time the E. huxleyi specific loss rate increased with increasing $\mathrm{P}$ loading. For these P-related losses 3 causes can be considered: (1) increased impact of grazers on E. huxleyi due to changed phytoplankton composition; (2) higher activity of E. huxleyi specific viruses; (3) increased concentrations of toxins, produced by co-occurring phytoplankton species. The second possible mechanism for P-stimulated loss rates is based on the observations of Bratbak et al. (1993) that lysis of E. huxleyi was related to the activity of viruses and that the proliferation of these viruses was enhanced by high phosphate concentrations. With respect to the third cause we report that with increasing phosphate loadings the relative abundance of Phaeocystis sp. and dinoflagellates increased (Egge \& Heimdal 1994). It is noteworthy that the phytoplankton standing stocks were rather high in the fertilized enclosures $\left(0.3\right.$ and $0.6 \mathrm{~g} \mathrm{C} \mathrm{m}^{-3}$ on 2 and $11 \mathrm{May}$, respectively, in Enclosure 5) compared to natural E. huxleyi blooms where values of 0.04 to $0.3 \mathrm{~g} \mathrm{C} \mathrm{m}^{-3}$ are typical (Balch et al. 1991, Fernandez et al. 1993, Kristiansen et al. 1994); the artificial conditions may have enhanced inter-species interactions. An argument against the third possibility is that toxins would probably also affect the gross growth rate of the E. huxleyi populations, yet this was not observed.

In the unfertilized Enclosure 4 the high Emiliania huxleyi specific loss rates may be partly explained by a high impact of grazing. An equal quantity of grazers in all enclosures imposes a much larger relative effect when phytoplankton biomasses are low. Unfortunately 
there are no experimental data available on meso- or microzooplankton grazing in this enclosure.

It is conceivable that the high losses in Enclosure 4 sustained the high gross growth rates observed in this enclosure at very low nutrient concentrations, and that the turnover rate of nutrients was high. If Enclosure 4 is indeed representative of oligotrophic conditions in the field, the production of calcium carbonate, and in general of refractive materials (rich in carbon) which are not readily recycled, may be much higher than the values which are presently accepted on the basis of cell counts or productivity measurements in blooms. The increasing amounts of particulate inorganic carbon (PIC; including attached and detached coccoliths) per Emiliania huxleyi cell in Enclosures 6, 3, 5 and 4 $\left(6.7,9.3,11.8\right.$ and $17.7 \pm 3.0 \mathrm{pg}$ PIC cell ${ }^{-1}$, respectively; Van Bleijswijk et al. 1994a) clearly illustrate the effect of high loss rates. In Enclosures 3 and 6 the PIC standing stock and the lipid biomarker concentrations increased at a rate comparable to the net $E$. huxleyi growth rate (Conte et al. 1994, Van Bleijswijk et al. 1994a). The increases in the PIC standing stock in Enclosures 5 and 4 were larger than the net increase in E. huxleyi cell numbers (resulting in the higher values of PIC per cell) but significantly smaller than the estimated gross growth rate. The observations indicate that with the loss of E. huxleyi cells, 75 to $80 \%$ of the corresponding amount of PIC is also assimilated.

\section{CONCLUSIONS}

At the onset of the Emiliania huxleyi blooms and during the mid-exponential increase of the populations, nutrient conditions did not limit E. huxleyi gross growth. Nutrient conditions did, however, influence $E$. huxleyi bloom formation: they clearly affected the specific loss rate of E. huxleyi populations, by profoundly changing the phytoplankton composition and biomass and thereby the impact of grazers on the coccolithophore. Under eutrophic conditions allopathy and phosphate-stimulated viral activity may also increase E. huxleyi losses.

In the future we hope to use the DNA method for mapping the horizontal and vertical variation of gross growth rate within Emiliania huxleyi blooms. Also, we want to see whether the absence of E. huxleyi blooms below $47^{\circ} \mathrm{N}$ in the Atlantic Ocean is due to slow gross growth. In general, we consider this method crucial for the verification in the field of hypotheses based on laboratory and model experiments, although it is quite laborious.

Acknowledgements. We thank Rob Kempers, Toomas Lukk and Pierre Bonnet for assistance during sampling; Dr J. K.
Egge for kindly providing data on cell counts and nutrients; and Dr C. Barranguet for her contribution to Fig. 3. Prof. J. Chang, Dr P. Westbroek and Dr G. C. Cacee are acknowledged for their suggestions for improving the manuscript. The research was carried out with financial support from the Netherlands Organisation for Scientific Research Working Group on the $\mathrm{CO}_{2}$ problem (NWO-CO ) and the National Research Program on Global Air Pollution and Climate Change (NOP). This is EHUX contribution 33.

\section{LITERATURE CITED}

Balch WM, Holligan PM, Ackleson SG, Voss KJ (1991) Biological and optical properties of mesoscale coccolithophore blooms in the Gulf of Maine. Limnol Oceanogr 36: 629-643

Brand LE (1982) Genetic variability and spatial patterns of genetic differentiation in the reproductive rates of the marine coccolithophores Emiliania huxleyi and Gephyrocapsa oceanica. Limnol Oceanogr 27(2):236-245

Bratbak G, Egge JK, Heldal M (1993) Viral mortality of the marine alga Emiliania huxleyi (Haptophyceae) and termination of algal blooms. Mar Ecol Prog Ser 93:39-48

Brown CW, Yoder JA (1994) Coccolithophorid blooms in the global ocean. J geophys Res 99(C4):7467-7482

Carpenter EJ, Chang J (1988) Species-specific phytoplankton growth rates via diel DNA synthesis cycles. I. Concept of the method. Mar Ecol Prog Ser 43:105-111

Chang J, Carpenter EJ (1988) Species-specific phytoplankton growth rates via diel DNA synthesis cycles. II. DNA quantification and model verification in the dinoflagellate Heterocapsa triquetra. Mar Ecol Prog Ser 44:287-296

Chang J, Carpenter EJ (1990) Species-specific phytoplankton growth rates via diel DNA synthesis cycles. IV. Evaluation of the magnitude of error with computer-simulated cell populations. Mar Ecol Prog Ser 65:293-304

Chang J, Carpenter EJ (1991) Species-specific phytoplankton growth rates via diel DNA synthesis cycles. V. Application to natural populations in Long Island Sound. Mar Ecol Prog Ser 78:115-122

Chang J, Carpenter EJ (1994) Active growth of the oceanic dinoflagellate Ceratium teres in the Caribbean and Sargasso seas estimated by cell cycle analysis. J Phycol 30 : $375-381$

Chang J, Dam HG (1993) The influence of grazing on the estimation of phytoplankton growth rate via cell cycle analysis: modelling and experimental evidence. Limnol Oceanogr 38(1):202-212

Charlson RJ, Lovelock JE, Andreae MO, Warren SG (1987) Oceanic phytoplankton, atmospheric sulphur, cloud albedo and climate. Nature 326:655-661

Conte MH. Thompson A, Eglinton G (1994) Primary production of lipid biomarker compounds by Emiliania huxleyi: results from an experimental mesocosm study in fjords of south-western Norway. Sarsia 79:319-331

Egge JK (1993) Nutrient control of phytoplankton growth: effects of macro nutrient composition (N, P, Si) on species succession. PhD thesis, University of Bergen

Egge JK, Heimdal BR (1994) Blooms of phytoplankton including Emiliania huxleyi (Haptophyta) in mesocosm experiments; effects of nutrient supply in different N.P ratios. Sarsia 79:333-348

Fernandez E, Boyd P. Holligan PM, Harbour DS (1993) Production of organic and inorganic carbon within a largescale coccolithophore bloom in the northeast Atlantic Ocean. Mar Ecol Prog Ser 97:271-285 
Holligan PM (1992) Do marine phytoplankton influence global climate? In: Falkowski PG, Woodhead AD (eds) Primary productivity and biogeochemical cycles in the sea. Plenum Press, New York, p 487-501

Howard A, Pelc RR (1953) Division of cell cycle in G1, S, G2 and M. Heredity 6 (Suppl):261

Kristiansen $S$, Thingstad TF, Van der Wal $P$, Farbrot $T$, Skjoldal EF (1994) An Emiliania huxleyi dominated flagellate bloom beneath the brackish layer of the Samnangerfjord, western Norway. Importance of hydrography and nutrients. Sarsia 79:357-368

Malin G, Turner SM, Liss P (1992) Sulfur The plankton/climate connection. J Phycol 28:590-597

McDuff RE, Chisholm SW (1982) The calculation of in situ growth rates of phytoplankton populations from fractions of cells undergoing mitosis: a clarification. Limnol Oceanogr 27:783-788

Nejstgaard JC, Witte HJ, Van der Wal P, Jacobsen A (1994) Micro and mesozooplankton grazing during a mesocosm study of an Emiliania huxleyi (Prymnesiophyceae) bloom. Sarsia 79:369-377

Van Bleijswijk JDL, Kempers ES, Van der Wal P, Westbroek P, Egge JK, Lukk T (1994a) Standing stocks of PIC, POC, PON and Emiliania huxleyi coccospheres and liths in seawater enclosures with different phosphate loadings. Sarsia 79:307-317

This article was submitted to the editor
Van Bleijswijk JDL, Kempers R, Veldhuis MJ, Westbroek $\mathrm{P}$ (1994b) Cell and growth characteristics of types A and B of Emiliania huxleyi (Prymnesiophyceae) as determined by flow cytometry and chemical analysis. J Phycol 30:230-241 Van Bleijswijk JDL, Van der Wal P, Kempers ES, Veldhuis MJW, Young JR, Muyzer G, De Vrind De Jong E, Westbroek P (1991) Distribution of two types of Emiliania huxleyi (Prymnesiophyceae) in the Northeast Atlantic region as determined by immunofluorescence and coccolith morphology. J Phycol 27:566-570

Van der Wal P, Van Bleijswijk JDL, Egge JK (1994) Primary productivity and calcification rate in blooms of the coccolithophorid Emiliania huxleyi (Lohmann) Hay et Mohler developing in mesocosms. Sarsia 79:401-408

Vaulot D (1992) Estimate of phytoplankton division rates by the mitotic index method: the $f_{\max }$ approach revisited. Limnol Oceanogr 37(3):644-649

Westbroek P, Brown CW, Van Bleijswijk J, Brownlee C Brummer GJ, Conte M, Egge J, Fernandez E, Jordan R, Knappertsbusch M. Stefels J, Veldhuis M, Van der Wal P, Young JR (1993) A model system approach to biological climate forcing. The example of Emiliania huxleyi. Global planet Change 8:1-20

Young JR, Westbroek P (1991) Genotypic variation within the coccolithophorid species Emiliania huxleyi. Mar Micropaleontol 18:5-23

Manuscript first received: October 20,1994

Revised version accepted: January 20, 1995 